\title{
VEGETATION STRUCTURE IN CERRADO PHYSIOGNOMIES IN SOUTH-EASTERN BRAZIL
}

\author{
BATALHA, M. A., MANTOVANI, W. and MESQUITA JÚNIOR, H. N. de \\ Instituto de Biociências, Universidade de São Paulo, C.P. 11.461, CEP 05422-970, São Paulo, SP, Brazil \\ Correspondence to: Marco Antônio Batalha, Programa de Pós-graduação em Ecologia, Instituto de Biociências, \\ USP, C.P. 11.461, CEP 05422-970, São Paulo, SP, Brazil, e-mail: marcobat@uol.com.br \\ Received February 10, 2000 - Accepted August 22, 2000 - Distributed August 31, 2001
}

(With 3 figures)

\begin{abstract}
We studied three cerrado physiognomies (campo cerrado, a savanna woodland; cerrado sensu stricto, a woodland; and cerradão, a tall woodland) in a reserve with 1,225 ha, in Santa Rita do Passa-Quatro (21 36 38'S and 47 $36-39^{\prime}$ W), São Paulo State, South-eastern Brazil, to compare plant communities structure. As descriptors of the vegetation structure, we used richness, density, basal area, cylindrical volume, and diversity. Ten $40 \mathrm{~m}^{2}$ quadrats were placed randomly in each physiognomy, in which we sampled the woody plants with stem diameter equal or larger than $1 \mathrm{~cm}$ (woody component), and ten $2.5 \mathrm{~m}^{2}$ quadrats, in which we sampled the woody plants with stem diameter smaller than $1 \mathrm{~cm}$ and all the non-woody individuals (herbaceous component). In the woody component, we found significant differences among the physiognomies for richness, density and cylindrical volume. Cylindrical volume increased from campo cerrado to cerradão, but richness and density were higher in cerrado sensu stricto. In the herbaceous component, we detected differences for all variables, which were higher in the savanna physiognomies, campo cerrado and cerrado sensu stricto, than in the forest physiognomy, cerradão. Cylindrical volume was the best variable to distinguish the physiognomies. Floristic similarity followed the campo cerrado-cerrado sensu strictocerradão gradient, and $\beta$ diversity was higher in the herbaceous component.
\end{abstract}

Key words: cerrado, phytosociology, physiognomy, diversity, South-eastern Brazil.

\section{RESUMO}

\section{Estrutura da vegetação em três fisionomias de cerrado em um fragmento no Estado de São Paulo}

Estudamos três fisionomias do cerrado (campo cerrado, cerrado sensu stricto e cerradão) em uma reserva

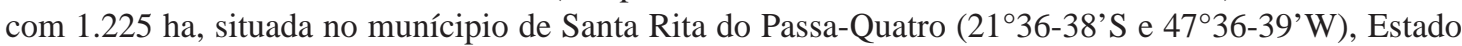
de São Paulo, com o objetivo de comparar a estrutura da vegetação, tanto do componente arbustivo-arbóreo quanto do herbáceo-subarbustivo. Como descritores da estrutura da comunidade, utilizamos a riqueza, a densidade, a área basal, o volume cilíndrico e a diversidade. Em cada uma das três fisionomias, lançamos aleatoriamente 10 parcelas de $40 \mathrm{~m}^{2}$, em que amostramos as plantas lenhosas com diâmetro do caule no nível do solo maior ou igual a $1 \mathrm{~cm}$ (componente arbustivo-arbóreo), com subparcelas de 2,5 $\mathrm{m}^{2}$, em que amostramos as plantas lenhosas com diâmetro do caule no nível do solo menor do que $1 \mathrm{~cm}$ e todas as não-lenhosas (componente herbáceo-subarbustivo). No componente arbustivo-arbóreo, encontramos diferenças significativas entre as fisionomias para a riqueza, a densidade e o volume cilíndrico. O volume cilíndrico aumentou do campo cerrado ao cerradão, enquanto a riqueza e a densidade foram maiores no cerrado sensu stricto. Para o componente herbáceo-subarbustivo, detectamos diferenças em todas as variáveis, que foram maiores nas fisionomias savânicas, campo cerrado e cerrado sensu stricto, do que nas fisionomias florestal e cerradão. $\mathrm{O}$ volume cilíndrico foi a melhor variável para distinguir diferenças entre as fisionomias. A similaridade florística seguiu o gradiente campo cerrado-cerrado sensu strictocerradão, e a diversidade $\beta$ foi maior para o componente herbáceo-subarbustivo.

Palavras-chave: cerrado, fitossociologia, fisionomia, diversidade, Pé-de-Gigante. 


\section{INTRODUCTION}

The cerrado is the second largest Brazilian biome, covering approximately two million $\mathrm{km}^{2}$, especially in the Central Highlands (Ratter et al., 1997). Disjunct areas also occur in other States, such as São Paulo (Ratter et al., 1997). The cerrado vegetation presents a wide physiognomic variation. According to the "forest-ecotone-grassland" concept (Coutinho, 1978), the cerrado ranges from campo limpo, a grassland, to cerradão, a tall woodland. The intermediate physiognomies (campo sujo - a shrub savanna, campo cerrado - a savanna woodland, and cerrado sensu stricto - a woodland) are considered ecotones of the two extremes. Since the limits among cerrado physiognomies are not well-defined (Goodland, 1979), all subdivisions of cerrado are more or less arbitrary. Even yet, there is no agreement on the cerrado physiognomic subdivision. For example, besides Coutinho's classification, there are other systems, such as those of Eiten (1979) and Ribeiro \& Walter (1998), in which the cerrado subdivision is even more detailed.

There are in the cerrado flora two components: the herbaceous and the woody, which are floristically distinct and antagonistic, because both are sun-loving (Coutinho, 1978). As a consequence, the cerrado floristic composition changes gradually across the physiognomic gradient (Eiten, 1977). Lopes \& Cox (1977) pointed out five theories proposed by several authors to explain the cerrado physiognomic gradient: water stress, fire, temporary flooding, oligotrophic scleromorphism, and aluminotoxic scleromorphism.

Some papers compared the structure of different cerrado physiognomies. Goodland (1971, 1979), for example, compared areas of campo sujo, campo cerrado, cerrado sensu stricto, and cerradão in Minas Gerais State and found increases in cover, height, density, basal area, and richness of trees from campo sujo to cerradão. Ribeiro et al. (1985) compared areas named by them as cerrado ralo, cerrado típico, and cerradão in Planaltina (Federal District) and observed increases towards cerradão in richness, density, basal area, height, and cover of trees. Ratter et al. (1988) analysed areas of cerrado sensu stricto and cerradão in Angatuba (São Paulo State), while Meira-Neto (1991) compared the same physiognomies in Águas de Santa Bárbara (São Paulo State). Mantovani (1990) analysed the similarity of the woody flora among campo cerrado, cerrado sensu stricto, and cerradão in Itirapina (São Paulo State) and considered campo cerrado and cerrado sensu stricto the most similar physiognomies. Uhlmann et al. (1998) compared campo cerrado and cerrado sensu stricto in Jaguariaíva (Paraná State) and found higher values of density, dominance, and diversity in the latter physiognomy. Of these studies, only Goodland (1971, 1979) sampled both the herbaceous and woody components.

Our aim in this study was to compare the structure and the floristic composition of three cerrado physiognomies (campo cerrado, cerrado sensu stricto, and cerradão), including the herbaceous component. The questions being asked were: is there an increase in the values of the vegetation descriptors (richness, density, basal area, biomass, and diversity) in the woody component from campo cerrado to cerradão, and a concomitant decrease, for the same descriptors, in the herbaceous component? Which is the best descriptor to distinguish these physiognomies?

\section{MATERIAL AND METHODS}

The Pé-de-Gigante Reserve is located in Santa Rita do Passa-Quatro, São Paulo State, between $21^{\circ} 36-39^{\prime} S$ and $47^{\circ} 36-38^{\prime} \mathrm{W}$, under Köppen's Cwag' climate type, with annual rainfall around $1,500 \mathrm{~mm}$, at 590 to $740 \mathrm{~m}$ high, on RedYellow Latosol (Pivello et al., 1998). Its name ("Péde-Gigante" or "Giant's foot") was given after a foot-shaped geomorphological formation decurrent in the Paulicéia Stream drainage. The study area covers 1,225 ha, composed mainly (98\% of the total area) of cerrado physiognomies (campo cerrado, cerrado sensu stricto, and cerradão). Since the reserve is surrounded by silviculture, it remains protected from fire, but is being invaded by alien grasses (Pivello et al., 1999b). A more detailed characterization of the study area can be found in Pivello et al. (1998, 1999a).

To compare the structure of these physiognomies, the reserve was initially mapped by remote sensing techniques, using a vegetation index which measures the green biomass, and with which the occurrence of cerrado physiognomies was assigned (Bitencourt et al., 1997; Pivello et al., 1999a). Using the digitalized image, ten points were randomly picked on each cerrado physiognomy (Fig. 1). At the end of the rainy season (March-April 1996), with the coordinates of each point, we tried to come 
as close as possible to each one of them with a Global Positioning System (GPS) receiver.

On each of these 30 points, we placed a $4 \times$ $10 \mathrm{~m}$ quadrat, in which we sampled the woody plants with stem diameter at soil level equal or larger than $1 \mathrm{~cm}$ (hereafter called "woody component" or "trees and shrubs"), and a $1 \times 2.5 \mathrm{~m}$ quadrat, in which we sampled the woody plants with stem diameter at soil level smaller than $1 \mathrm{~cm}$ and all non-woody ones (hereafter called "herbaceous component" or "herbs and subshrubs").

The basal area of herbaceous plants was calculated by taking their diameter at soil level. We considered the branches of soboliferous species in a given quadrat as belonging to the same individual. In the small quadrat, we avoided sampling seedlings, defined here as those plants still with cotyledons, due to their dynamic through the year.

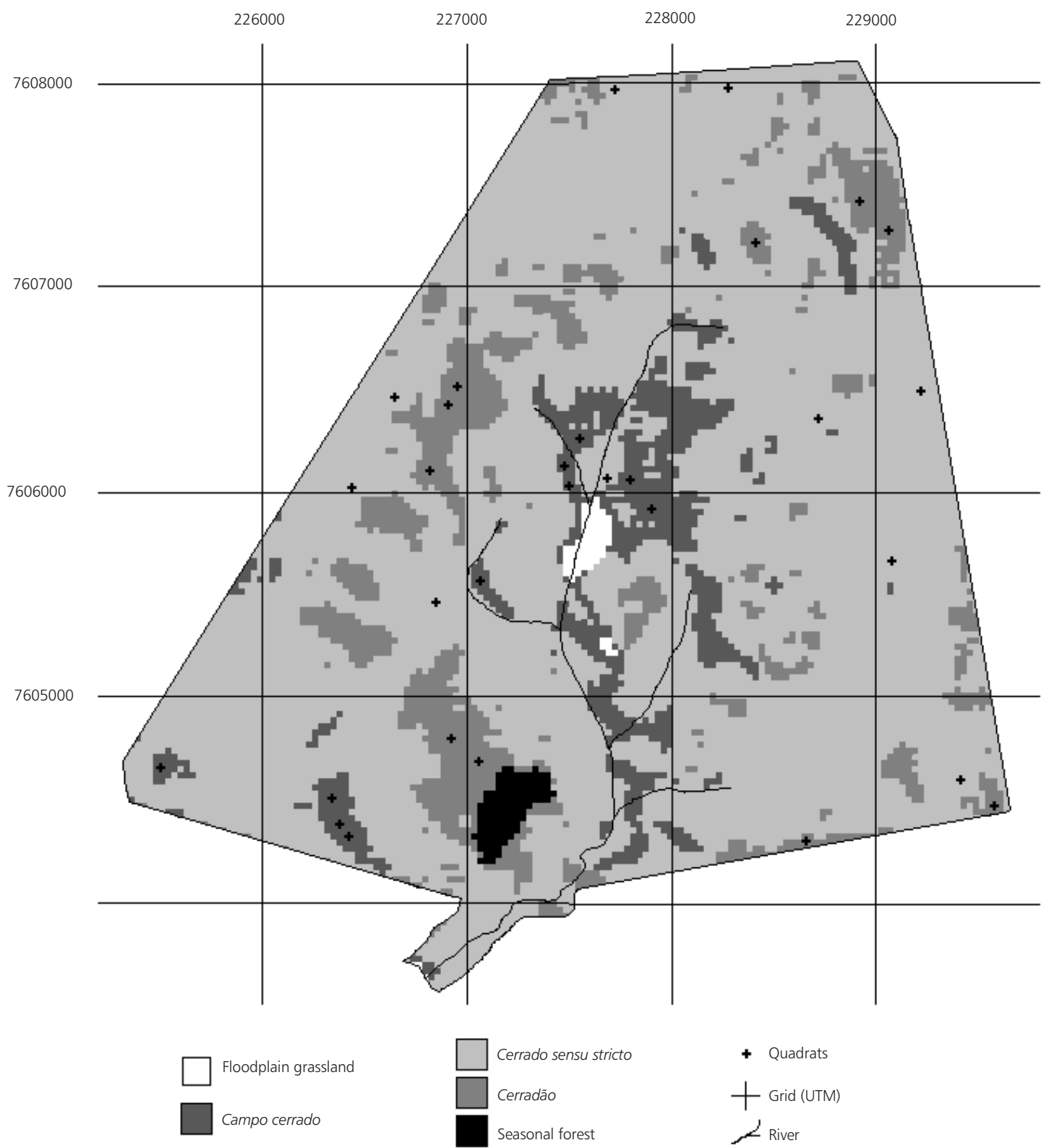

Fig. 1 - Location of quadrats in the Pé-de-Gigante Reserve, Santa Rita do Passa-Quatro, São Paulo, Brazil (2136-38'S and 47 $\left.36-39^{\prime} \mathrm{W}\right)$, redrawn after Pivello et al. (1999a). 
Botanical material was collected and identified by comparison with fertile material and with an identification key based on vegetative characters (Batalha \& Mantovani, 1999).

For each physiognomy and each component, we analysed the following variables: richness (number of species), density (ind $\cdot \mathrm{ha}^{-1}$ ), basal area $\left(\mathrm{m}^{2} \cdot \mathrm{ha}^{-1}\right)$, cylindrical volume $\left(\mathrm{m}^{3} \cdot \mathrm{ha}^{-1}\right)$, and diversity (nats $\cdot$ ind $^{-1}$ ). For each sampling unit, we calculated these variables as follows: i) richness: number of species found, ii) density: $\mathrm{n} \cdot\left(\mathrm{U} \cdot \mathrm{A}^{-1}\right)$, iii) basal area: $\mathrm{BA} \cdot\left(\mathrm{U} \cdot \mathrm{A}^{-1}\right)$, iv) cylindrical volume: $(\mathrm{BA} \cdot \mathrm{h})\left(\mathrm{U} \cdot \mathrm{A}^{-1}\right)$; where $\mathrm{n}=$ number of individuals, $\mathrm{U}=10.000 \mathrm{~m}^{2}, \mathrm{~A}=$ sampled area $(40$ $\mathrm{m}^{2}$ or $\left.2.5 \mathrm{~m}^{2}\right), \mathrm{BA}=$ basal area $\left(\mathrm{m}^{2}\right)$ and $\mathrm{h}=$ height $(\mathrm{m})$. Density and basal area were calculated following Mueller-Dombois \& Ellenberg (1974) and cylindrical volume, according to Castro (1987). Diversity was estimated by the Shannon index (Shannon \& Weaver, 1963).

For all these variables except for diversity, we tested for normality (Shapiro \& Wilk, 1965) and homocedasticity (Hartley, 1950). When the variables did not satisfy these criteria, they were either square root or logarithm transformed. Next, we carried out a one-way analysis of variance (ANOVA) to detect significant differences, and the least square significant (LSD) test of multiple comparisons (Zar, 1999) to distinguish means. We also calculated the power of the test (Zar, 1999), and, when this value was lower than $80 \%$, the number of sampling units required to reach it. We employed Hutcheson's test (Zar, 1999) to compare diversity index values between all possible pairs. Thus, we could not calculate the power of the test for this variable. The whole procedure was followed for both the woody and the herbaceous components.

Finally, we analysed the diversity among physiognomies, calculating for each component the similarity at species level through the Sørensen and Bray \& Curtis indices (Magurran, 1988). To depict these relations, we constructed clusters, grouping the average values (Jongman et al., 1995).

\section{RESULTS}

Woody component - in campo cerrado, we sampled 621 individuals, representing 87 species; in cerrado sensu stricto, 687 individuals, belonging to 84 species; and, in cerradão, 495 individuals, from 75 species.
The test of normality showed that basal area and cylindrical volume were not normally distributed. In both cases, the original data were logtransformed. Only density presented heterogenous variances $(0.05>p>0.01)$, which was not corrected by any transformation. However, as the ANOVA is robust enough to operate well even with heterogenous variances, since the experiment is balanced (Zar, 1999), we decided to use these data.

We found significant difference among physiognomies for richness $(\mathrm{p}=0.044)$, density $(\mathrm{p}=0.024)$ and cylindrical volume $(\mathrm{p}<0.001)$. Basal area was not significantly different ( $\mathrm{p}=$ 0.117). Richness of trees and shrubs was significantly higher in cerrado sensu stricto in relation to campo cerrado and cerradão (Table 1). Density increased from cerradão, through campo cerrado, to cerrado sensu stricto. The difference was statistically significant only between cerradão and cerrado sensu stricto. For basal area, although we found an increase from campo cerrado to cerradão, it was not significant. Cylindrical volume also increased from campo cerrado to cerradão, with values differing significantly. Diversity decreased from campo cerrado to cerradão, although the differences were not significant.

The ANOVA for richness, density, and basal area presented low power. These values were $44 \%$ for richness, $57 \%$ for density, and $25 \%$ for basal area (Table 1). The sampling size required to reach the power of the test of at least $80 \%$ would be, respectively, 21, 16, and 37 sampling units (Table 2 ). Only for cylindrical volume, the power of the test was high $(100 \%)$, and therefore the number of sampling units was representative.

The most similar physiognomies (Fig. 2) were campo cerrado and cerrado sensu stricto (Sørensen index $=0.702$ ). The next highest value was between cerrado sensu stricto and cerradão (0.679) and, the least, between campo cerrado and cerradão $(0.568)$.

Using the Bray-Curtis index, the most similar physiognomies were cerrado sensu stricto and cerradão (0.604); between campo cerrado and cerrado sensu stricto, the value was 0.391 and between campo cerrado and cerradão, 0.317.

Herbaceous component - in campo cerra$d o$, we sampled 714 individuals, belonging to 81 species; in cerrado sensu stricto, 399 individuals, 
from 81 species; and in cerradão, 301 individuals, of 65 species.

Density, basal area, and cylindrical volume were not normally distributed, which was corrected using the square root of density and the logarithm of both basal area and cylindrical volume.

All variables had homogeneous variances, after transformations. Statistically significant differences were found among physiognomies for all variables: richness $(\mathrm{p}=0.015)$, density $(\mathrm{p}<$ $0.001)$, basal area $(\mathrm{p}<0.001)$, and cylindrical vo- lume $(\mathrm{p}<0.001)$. For herbs and subshrubs, richness was significantly higher in campo cerrado and cerrado sensu stricto in relation to cerradão (Table 1). Density in campo cerrado was considered significantly higher than in cerrado sensu stricto and in cerradão. Both basal area and cylindrical volume were significantly higher in campo cerrado and cerrado sensu stricto in relation to cerradão. Diversity of cerrado sensu stricto was considered significantly higher than diversity of the other two physiognomies.

TABLE 1

Structure descriptors for woody and herbaceous components in three cerrado physiognomies (Pé-de-Gigante

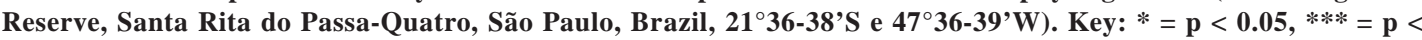
$0.001, \mathrm{~ns}=$ non significant, $1-\beta=$ power of the test (for $\alpha=0.05$ ). Values are mean \pm 1 SD. Significant differences among means are shown by different letters.

\begin{tabular}{|c|c|c|c|c|c|}
\hline \multicolumn{6}{|c|}{ Physiognomy } \\
\hline Descriptor & Campo cerrado & Cerrado sensu stricto & Cerradão & $\mathbf{P}$ & $1-\beta$ \\
\hline \multicolumn{6}{|l|}{ Woody component } \\
\hline Richness & $21.9^{\mathrm{a}} \pm 5.4$ & $26.5^{\mathrm{b}} \pm 4.2$ & $21.8^{\mathrm{a}} \pm 3.8$ & $*$ & $44 \%$ \\
\hline Density (ind $\cdot \mathrm{ha}^{-1}$ ) & $15,525^{\mathrm{ab}} \pm 4,910$ & $17,175^{\mathrm{b}} \pm 3,719$ & $12,375^{\mathrm{a}} \pm 1,819$ & $*$ & $57 \%$ \\
\hline Basal area $\left(\mathrm{m}^{2} \cdot \mathrm{ha}^{-1}\right)$ & $49.18 \pm 22.34$ & $49.92 \pm 12.19$ & $68.12 \pm 33.34$ & ns & $25 \%$ \\
\hline Cylindrical volume $\left(\mathrm{m}^{3} \cdot \mathrm{ha}^{-1}\right)$ & $69.11^{\mathrm{a}} \pm 29.29$ & $164.79^{\mathrm{b}} \pm 62.50$ & $428.47^{\mathrm{c}} \pm 369.18$ & $* * *$ & $100 \%$ \\
\hline Diversity (nats $\cdot$ ind $^{-1}$ ) & $3.74 \pm 0.05$ & $3.71 \pm 0.04$ & $3.65 \pm 0.05$ & ns & - \\
\hline \multicolumn{6}{|l|}{ Herbaceous component } \\
\hline Richness & $16.9^{\mathrm{b}} \pm 6.01$ & $17.5^{\mathrm{b}} \pm 3.44$ & $11.6^{\mathrm{a}} \pm 4.03$ & $*$ & $62 \%$ \\
\hline Density (ind $\cdot \mathrm{ha}^{-1}$ ) & $285,600^{\mathrm{b}} \pm 91,178$ & $159,600^{\mathrm{a}} \pm 42,350$ & $120,400^{\mathrm{a}} \pm 80,541$ & $* * *$ & $99 \%$ \\
\hline Basal area $\left(\mathrm{m}^{2} \cdot \mathrm{ha}^{-1}\right)$ & $128.61^{\mathrm{b}} \pm 111.33$ & $52.08^{\mathrm{b}} \pm 37.94$ & $9.47^{\mathrm{a}} \pm 15.28$ & $* * *$ & $100 \%$ \\
\hline Cylindrical volume $\left(\mathrm{m}^{3} \cdot \mathrm{ha}^{-1}\right)$ & $95.98^{\mathrm{b}} \pm 86.80$ & $38.39^{\mathrm{b}} \pm 37.20$ & $4.47^{\mathrm{a}} \pm 7.72$ & $* * *$ & $100 \%$ \\
\hline Diversity (nats $\cdot$ ind $^{-1}$ ) & $3.46^{\mathrm{a}} \pm 0.05$ & $3.55^{\mathrm{b}} \pm 0.07$ & $3.48^{\mathrm{ab}} \pm 0.07$ & * & - \\
\hline
\end{tabular}

TABLE 2

Sampling size required to obtain a power of test of at least $80 \%$ (for $\alpha=0.05$ ) in structure descriptors of woody and herbaceous component in three cerrado physiognomies (Pé-de-Gigante Reserve, Santa Rita do Passa-Quatro, São Paulo, Brazil, 21 ${ }^{\circ} 36-38$ 'S e $\left.47^{\circ} 36-39^{\prime} W\right)$. Key: $\mathrm{s}^{2}=$ residual mean square, $\delta$ = minimum detectable difference, $\mathrm{n}=$ sampling size required, $1-\beta=$ power of the test.

\begin{tabular}{|l|c|c|c|c|}
\hline Descriptor & $\mathbf{s}^{\mathbf{2}}$ & $\boldsymbol{\delta}$ & $\mathbf{n}$ & $\mathbf{1}-\boldsymbol{\beta}$ \\
\hline Woody component & 20.556 & 4.53 & 21 & $82 \%$ \\
\hline Richness & 0.138 & 0.43 & 16 & $81 \%$ \\
\hline Density & 0.026 & 0.12 & 37 & $80 \%$ \\
\hline Basal area & 21.400 & 5.80 & 14 & $81 \%$ \\
\hline Herbaceous component
\end{tabular}


Contrary to the woody component, a high power for the ANOVA of the herbaceous component (Table 1) was found for density (99\%), basal area (100\%), and cylindrical volume (100\%); only richness presented low power $(62 \%)$. For this variable, the sampling size required to obtain the power of approximately $80 \%$ would be 14 quadrats (Table 2).

The most similar physiognomies (Fig. 3) were cerrado sensu stricto and cerradão (Sørensen index = 0.548); between campo cerrado and cerrado sensu stricto, the value was 0.531 and between campo cerrado and cerradão, 0.479. Using the Bray-Curtis index, the most similar physiognomies were also cerrado sensu stricto and cerradão (0.460); between campo cerrado and cerrado sensu stricto, it was 0.273; and between campo cerrado and cerradão, 0.185 .

\section{DISCUSSION}

Other papers that compared the structure of different cerrado physiognomies found increases in richness, density, and basal area for the woody component from open to closed physiognomies. Goodland (1971) observed increases from campo sujo to cerradão in richness, density, basal area, and cover, although he did not discuss if these differences were significant or not. Ribeiro et al. (1985) found increases from cerrado ralo to cerradão in richness, density, basal area, average height, and cover, but they also did not discuss the significancy of such differences. Uhlmann et al. (1998) found significant differences between campo cerrado and cerrado sensu stricto in richness, density, basal area, and diversity. Both Goodland (1971) and Ribeiro et al. (1985) sampled all woody individuals with stem perimeter equal or larger than $10 \mathrm{~cm}$ (or approximately $3 \mathrm{~cm}$ ), while Uhlmann et al. (1998) sampled the woody individuals with stem perimeter equal or largar than $15 \mathrm{~cm}$ (or approximately $5 \mathrm{~cm}$ ).

We did not find a clear increase of variables from campo cerrado to cerradão for the woody component. Our results showed that richness and density of trees and shrubs are higher in savanna physiognomies, notably in cerrado sensu stricto, and not in the cerradão. These results can be expected since, in the savanna physiognomies, we find species from both extremes of the cerrado physiognomic gradient. Density must indeed be higher in cerrado sensu stricto since the size of trees and shrubs is lower there than in cerradão.
For richness and density in the woody component, despite the low power of the tests, we could detect significant differences among the three physiognomies, which was not detected for basal area. Since the power of the test for this last variable was very low $(25 \%)$, there is a high probability of commiting type II error, that is, accepting the null hypothesis that all means are equal when actually they are not. Goodland (1971) considered basal area as the best variable to distinguish the cerrado physiognomies.

In the woody component, at least for richness, density, and basal area, the number of sampling units was considered low. In these cases, to obtain a representative sampling and a power of test of $80 \%$, we should have placed from 16 (for density) to 37 (for basal area) sampling units. Instead of a higher number of sampling units, maybe we could have used larger quadrats, which perhaps could provide more homogeneous samples.

Cylindrical volume was the most efficient descriptor to distinguish differences in the woody component among the three physiognomies. Total cylindrical volume can be used as an estimator of biomass, even though it frequently overestimates (Castro, 1987). In the sampled physiognomies, there was biomass increase from campo cerrado to cerradão, as expected. Goodland (1971), Ribeiro et al. (1985), and Uhlmann et al. (1998) did not calculate the cylindrical volume for their data, but if they had, probably they would have found an increase in this variable towards closed physiognomies, since, for them, both basal area and height increased in this direction.

For the herbaceous component, we expected an opposite pattern to the woody one, that is, decrease in richness, density, basal area, and cylindrical volume from campo cerrado to cerradão. Since both floras are heliophilous (Coutinho, 1978), the increase in tree cover, and consequently in shading, from campo cerrado to cerradão implies a decrease in the importance of the herbaceous component.

With our data for the herbaceous component, we could observe, generally, decreases in the variables from campo cerrado and cerrado sensu stricto to cerradão. The herbaceous component presents a seasonal variation much greater than the woody component (Goodland, 1971), therefore, depending on the time of the year in which the sample is taken, 
the results can be completely different. Yet, since we carried out our survey at the end of the rainy season, the herbaceous component should present its largest development (Sarmiento, 1984) and possible differences among physiognomies would be stressed.

Shannon's diversity index is an indication of community structure, and shows the diversity within a community considered homogeneous (Mantovani, 1996), or $\alpha$ diversity (Whittaker, 1977). For the woody component, the $\alpha$ diversity was not significantly different among the three physiognomies, despite its decrease from campo cerrado to cerradão. These results were not what was previously supposed, that is, the closer the physiognomy, the higher the diversity of trees and shrubs. For the herbaceous component, diversity was higher in cerrado sensu stricto, when compared to campo cerrado, and equal in cerradão in relation to the other two physiognomies. This is not in accordance with the initial hypotheses also, $i$. e., diversity of herbs and subshrubs decreases from campo cerrado to cerradão. Since we compared diversity index values between all possible pairs, the significant level was actually higher (Zar, 1999). In our case, as long as we had three possible combinations, and did each test at 0.05 significancy level, the probability of incorretly rejecting the null hypothesis (type I error) was $0.14\left(=1-0.95^{3}\right)$.
Thus, the probability of rejecting the null hypothesis that all index values were equal when in fact they were not was $14 \%$. Anyway, the hypothesis that the woody component diversity increases towards closed physiognomies, while the herbaceous component diversity decreases, was not confirmed. Similar to richness, maybe the diversity of the cerrado is higher in the savanna physiognomies of the "woodland-ecotone-grassland" concept, and not in its extremes.

One of the ways of measuring betweenhabitats diversity, or $\beta$ diversity (Whittaker, 1977), is through similarity indices (Mantovani, 1996), such as Sørensen and Bray-Curtis indices. Sørensen index is used to compare communities qualitatively, while Bray-Curtis index is a quantitative modification of Sørensen index (Magurran, 1988). The indices values pointed out that the similarity has always followed the "campo cerrado - cerrado sensu stricto - cerradão" gradient. In the woody component, the most similar physiognomies varied, depending on the index used: according to Sørensen index, the most similar physiognomies were cerrado sensu stricto and campo cerrado; but, according to Bray-Curtis index, the most similar physiognomies were cerrado sensu stricto and cerradão.
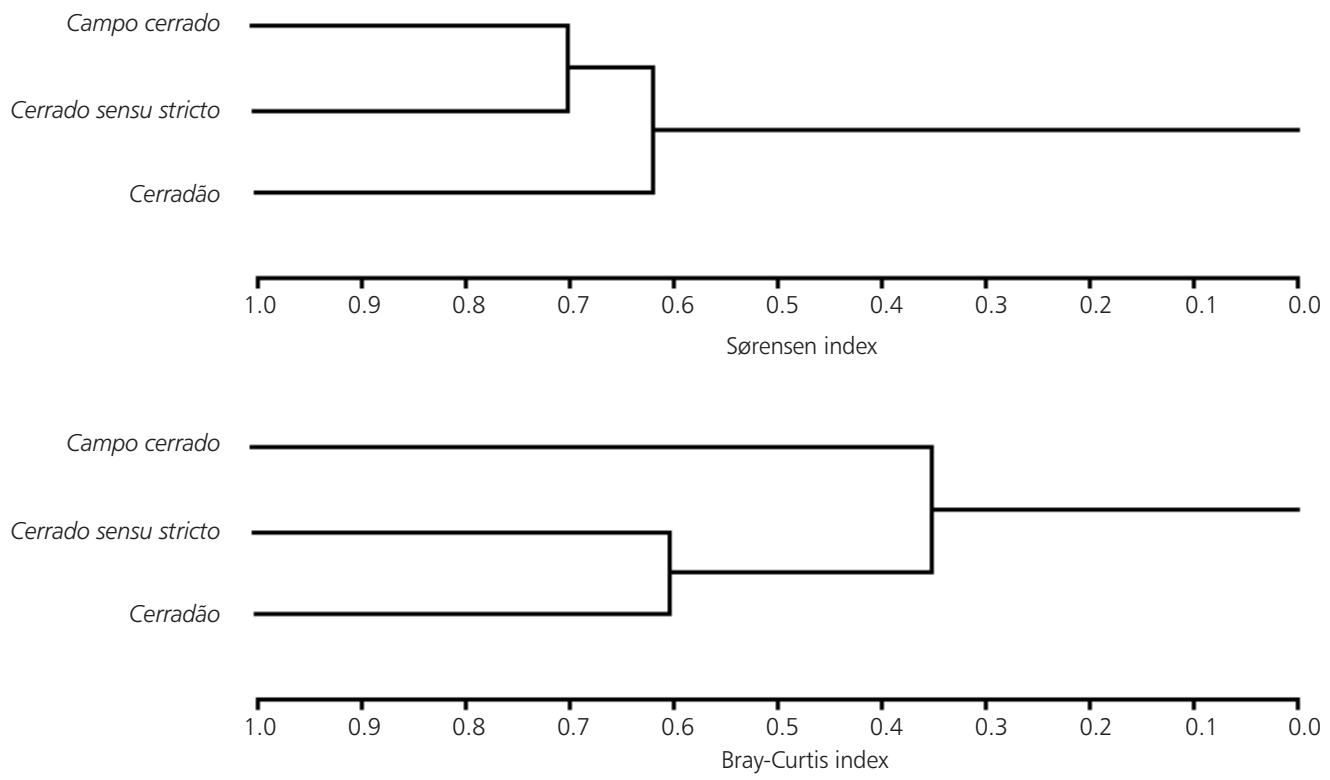

Fig. 2 - Similarity cluster of the woody component among three cerrado physiognomies (Pé-de-Gigante Reserve, Santa Rita do Passa-Quatro, São Paulo, Brazil, 21 ${ }^{\circ} 36-38^{\prime} S$ and 47³6-39’W), according to Sørensen and Bray-Curtis indices. 

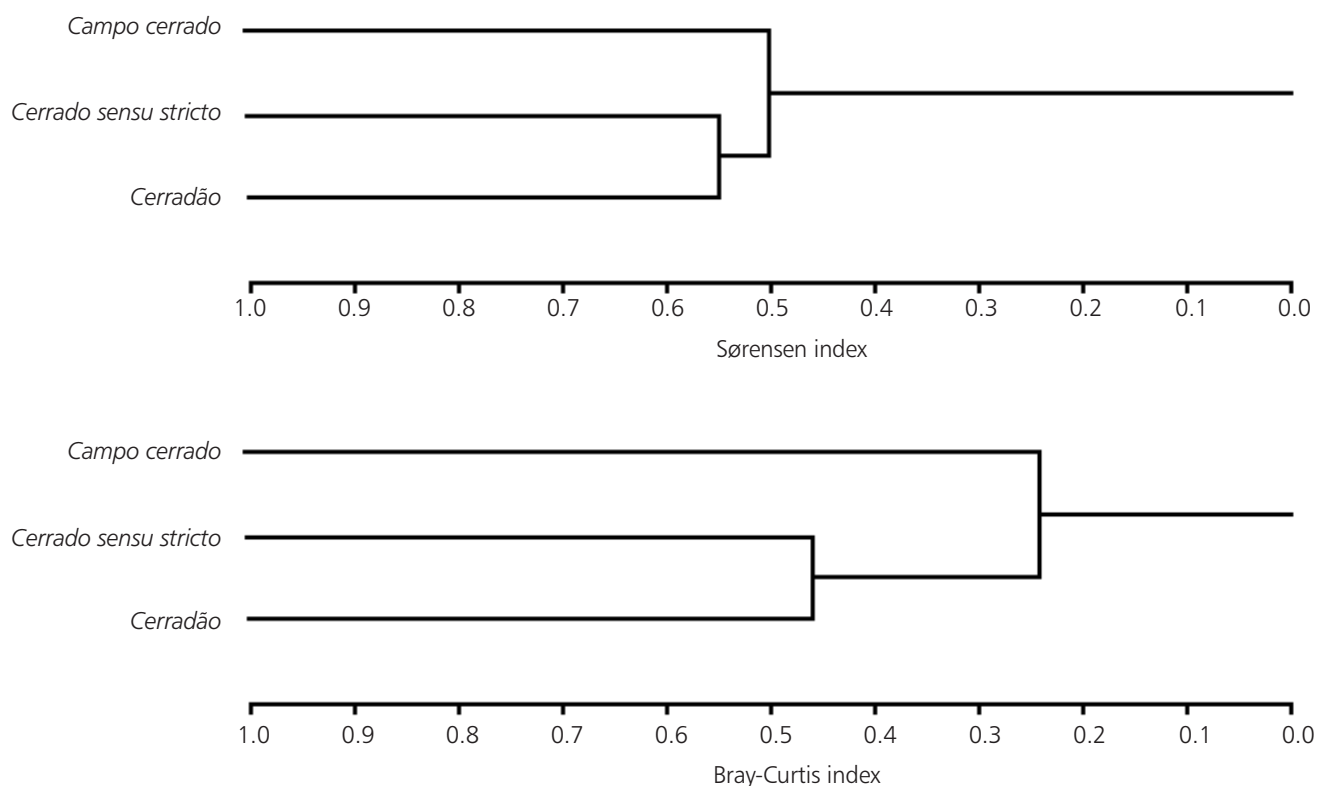

Fig. 3 - Similarity cluster of the herbaceous component among three cerrado physiognomies (Pé-de-Gigante Reserve, Santa Rita do Passa-Quatro, São Paulo, Brazil, 21 ${ }^{\circ} 36-38^{\prime}$ 'S and 47³6-39’ W), according to Sørensen and Bray-Curtis indices.

These results show that if the cerrado sensu stricto was floristically closer to campo cerrado, when we took into account the abundance of species, the cerrado sensu stricto was more similar to cerradão. Mantovani (1990) also found higher floristic similarity in the woody component between campo cerrado and cerrado sensu stricto and lower one between campo cerrado and cerradão.

In the herbaceous component, according to both indices, the most similar physiognomies were cerrado sensu stricto and cerradão. Although both indices presented the same pattern, when we used the quantitative index, the differences among physiognomies were emphasized. The similarity values of the herbaceous component were lower than those of the woody component, showing that the former has a higher $\beta$ diversity than the latter. The cerrado floristic unity seems to be determined especially by the woody flora, more homogeneous than the herbaceous one along the physiognomic gradient.

If we had used another criterion to define the herbaceous and woody components, such as lifeform, perhaps we could have found other results. We must make restrictions to comparisons with other papers (Goodland, 1971, 1979; Ribeiro et al., 1985; Mantovani, 1990; Uhlmann et al., 1998), since, in every one of them, there were differences in the definition of the physiognomies, in their recognition in field, in the definition of the components, and in the inclusion criterion. In spite of its importance, papers on the herbaceous component are virtually nonexistent (Castro et al., 1999). Future studies that intend to compare the structure of cerrado physiognomies should include also the herbaceous component and, when possible, sample all physiognomies, from campo limpo to cerradão, which would allow more wide conclusions.

Aknowledgments - We are grateful to Fapesp, for financial support conceded to the first author (process 95/4290-3); to Sônia Aragaki, for field assistance; to São Paulo Forestry Institute, for research license (process 43332/95); and to an anonymous reviewer, for helpful comments.

\section{REFERENCES}

BATALHA, M. A. \& MANTOVANI, W., 1999, Chaves de identificação das espécies vegetais vasculares baseada em caracteres vegetativos para a Arie Cerrado Pé-deGigante (Santa Rita do Passa-Quatro, SP). Revta. Inst. Flor., 11: 137-158. 
BITENCOURT, M. D., MESQUITA JR., H. N. DE, MANTOVANI, W., BATALHA, M. A. \& PIVELLO, V. R., 1997, Identificação de fisionomias de cerrado com imagem índice de vegetação. In: L. L. Leite \& C. H. Saito (eds.), Contribuição ao conhecimento ecológico do cerrado. Universidade de Brasília, Brasília, pp. 316-320.

CASTRO, A. A. J. F., 1987, Florística e fitossociologia de um cerrado marginal brasileiro, Parque Estadual de Vassununga, Santa Rita do Passa-Quatro, SP. Dissertação de Mestrado, Universidade Estadual de Campinas.

CASTRO, A. A. J. F., MARTINS, F. R., TAMASHIRO, J. Y. \& SHEPHERD, G. J., 1999, How rich is the flora of the Brazilian cerrados? Ann. Miss. Bot. Gard., 86: 192-224.

COUTINHO, L. M., 1978, O conceito do cerrado. Revta. Brasil. Bot., 1: 17-23.

EITEN, G., 1977, Delimitação do conceito do cerrado. Arq. J. Bot., 21: 125-134.

EITEN, G., 1979, Formas fisionômicas do cerrado. Revta, Brasil. Bot., 2: 139-48.

GOODLAND, R., 1971, A physiognomic analysis of the 'cerrado' vegetation of Central Brazil. J. Ecol., 59: 411419.

GOODLAND, R., 1979, Análise ecológica da vegetação do cerrado. In: M. G. Ferri \& R. Goodland (eds.), Ecologia do cerrado. Itatiaia, Belo Horizonte e EDUSP, São Paulo, pp. 61-193.

HARTLEY, H. O., 1950, The maximum F-ratio as a short cut test for heterogeneity of variances. Biometr., 37: 308-312.

JONGMAN, R. H. G., TER BRAAK, C. J. F. \& VAN TONGEREN, O. F. R., 1995, Data analysis in community and landscape ecology. Cambridge University, Cambridge.

LOPES, A. S. \& COX, F. R., 1977, Cerrado vegetation in Brazil: an edaphic gradient. Agronomy J., 69: 828-831.

MAGURRAN, A. E., 1988, Ecological diversity and its measurement. Princeton University, Princeton.

MANTOVANI, W., 1990, Variação da flora arbustivo-arbórea de diversas fisionomias de cerrado em Itirapina, Estado de São Paulo. In: CONGR. SOC. BOT. BRAS. 41, Curitiba, 1990. Anais. Soc. Bot. Brasil, Curitiba, pp. 125135.

MANTOVANI, W., 1996, Methods for assessment of terrestrial phanerogams biodiversity. In: C. E. M. Bicudo \& N. A. Menezes (eds.), Biodiversity in Brazil: a first approach. CNPq, São Paulo.

MEIRA-NETO, J. A. A., 1991, Composição florística e estrutura fitossociológica de fisionomias de cerrado "sensu lato" da Estação Ecológica de Santa Bárbara, Município de Águas de Santa Bárbara, Estado de São Paulo. Dissertação de Mestrado, Universidade Estadual de Campinas.
MUELLER-DOMBOIS, D. \& ELLENBERG, H., 1974, Aims and methods of vegetation ecology. John Willey \& Sons, New York.

PIVELLO, V. R., BITENCOURT, M. D., MANTOVANI, W., MESQUITA JR., H. N. DE, BATALHA, M. A. \& SHIDA, C., 1998, Proposta de zoneamento ecológico para a reserva de cerrado Pé-de-Gigante (Santa Rita do Passa-Quatro, SP). Revta. Brasil. Ecol., 2: 108-118.

PIVELLO, V. R., BITENCOURT, M. D., MESQUITA JR., H. N. DE \& BATALHA, M. A., 1999a, Banco de dados em SIG para Ecologia Aplicada: exemplo do Cerrado Pé-deGigante, SP. Cad. Inf. Geo., 1: http://www.cpa. unicamp.br/revista/cigv1n3a4.

PIVELLO, V. R., SHIDA, C. N. \& MEIRELLES, S. T., 1999b, Alien grasses in Brazilian savannas: a threat to the biodiversity. Biodiv. Cons., 8: 1281-1294.

RATTER, J. A., LEITÃO-FILHO, H. DE F., ARGENT, G., GIBBS, P. E., SEMIR, J., SHEPHERD, G. J. \& TAMASHIRO, J. Y., 1988, Floristic compostion and community structure of a southern cerrado area in Brazil. Notes R. Bot. Gard. Edinb., 45: 137-151.

RATTER, J. A., RIBEIRO, J. F. \& BRIDGEWATER, S., 1997, The Brazilian cerrado vegetation and threats to its biodiversity. Ann. Bot., 80: 223-30.

RIBEIRO, J. F., SILVA, J. C. S. \& BATMANIAN, G. J., 1985, Fitossociologia de tipos fisionômicos de cerrado em Planaltina, D. F. Revta. Brasil. Bot., 8: 131-42.

RIBEIRO, J. F. \& WALTER, B. M. T., 1998, Fitofisionomias do bioma Cerrado. In: S. M. Sano \& S. P. de Almeida (eds.), Cerrado: ambiente e flora. Embrapa, Brasília, pp. 89-166.

SARMIENTO, G., 1984, The ecology of neotropical savannas. Harvard University, Cambridge.

SHANNON, C. E. \& WEAVER, W., 1963, The mathematical theory of communication. University of Illinois, Urbana.

SHAPIRO, S. S. \& WILK, M. B., 1965, An analysis of variance test for normality (complet samples). Biom., 52: 591-611.

UHLMANN, A., GALVÃO, F. \& SILVA, S. M., 1998, Análise da estrutura de duas unidades fitofisionômicas de savana (cerrado) no sul do Brasil. Acta Bot. Bras. 12: 231-47.

WHITTAKER, R. H., 1977, Evolution of species diversity in land communities. In: M. K. Hecht, W. C. Steere \& B. Wallace (eds.), Evolutionary biology. Plenum, New York.

ZAR, J. H., 1999, Biostatistical analysis. Prentice-Hall, New Jersey. 